\author{
Nataliya Kashevarova, \\ Candidate of Sciences (History), \\ Senior Researcher \\ of Department for Special Branches of Historical Science \\ and Electronic Information Resources \\ of Institute of History of Ukraine, \\ of National Academy of Sciences of Ukraine \\ ORCID: 0000-0003-2426-044 \\ e-mail: nataliya.kashevarova@gmail.com
}

\title{
DOCUMENTS OF MAIN OFFICE FOR SCIENCE OF ROSENBERG OFFICE AS SOURCES ON IDEOLOGICAL COMPONENT OF NAZI POLICY IN OCCUPIED TERRITORY OF EASTERN EUROPE DURING WORLD WAR II
}

The purpose of the research is to characterize the documents of the Main Office for Science (German: Haupamt Wissenschaft) by the Commissioner of the Fuehrer for the Supervision of the Entire Intellectual and Ideological Schooling and Training of the NSDAP (German: Beauftragter des Führers für die Überwachung der gesamten geistigen und weltanschaulichen Schulung und Erziehung der NSDAP, and related materials of A. Rosenberg's other structures as the sources on the ideological component of the Third Reich's struggle against Bolshevism and their significance for information or ideological component of the Nazi occupation policy in the occupied territories of Eastern Europe. The research methodology consists of historical-archival, historical-comparative research methods, source analysis methods. The scientific novelty is determined by the fact that the materials of the Rosenberg Office and the documents of the Main Office for Science, in particular, have not yet been the subject of a separate comprehensive scientific archival and source review for their possible use as the historical sources on the ideological component of Nazi policy, vision of connection between science and ideology, participation of the Main Office for Science in the so-called "ideological struggle" against Bolshevism, collection of scientific information in the occupied territories of Eastern Europe, in particular, the USSR. Although these documents are familiar to German researchers, the latter used them as the sources to determine the Rosenberg Office's place in the NSDAP system and its significance for domestic party policy in the Third Reich. Conclusions. The analysis of the documents from the Main Office for Science of the Rosenberg Office allows us to conclude that a number of his documents for 1942-1945, as well as related documents of the Special Staff Science (German: Sonderstab Wissenschaft), which represented the interests of the department at the Special Command Force of Reichsleiter Alfred Rosenberg or Reichsleiter Rosenberg Taskforce (German: Einsatzstab Reichsleiter Rosenberg), contain the interesting and valuable information not only on the connection between National Socialist ideology and science but also on the collection and processing of various information about the state of science in the Soviet Union, especially the materials of scientific content, consolidated data about state of Soviet scientific institutions during the Nazi occupation, etc. This information has so far been little known or not introduced into scientific circulation at all, but it may be useful to researchers of the history of World War Il. 
Key words: World War II, Main Office for Science by the Commissioner of the Fuehrer for the Supervision of the Entire Intellectual and Ideological Schooling and Training of the NSDAP, Special Staff Science, Reichsleiter Rosenberg Taskforce, ideology, propaganda, Bolshevism

Relevance of the research topic. Researchers on the occupation policy of National Socialism in Eastern Europe, and directly in the occupied territory of the USSR during World War II, primarily its ideological component, traditionally in their studies consider the policy of Nazi administrative structures and services and its ideological component in their activities directly in the territories, occupied by the Nazis. In some places, the subject becomes the ideology of Nazism as a whole as a phenomenon. But, for example, the activities of individual structures within National Socialist Wor kers' Party of Germany (hereinafter - NSDAP, as it sounds in German, abbreviation «NSDAP» - «Nationalsozialistische Deutsche Arbeiterpartei»), which during World War II were in the territory of the Third Reich and were associated with Nazi politics in the territories, occupied by them, as well as its various components, such as the question about the role of the connection between ideology and science in the NSDAP, their influence on the Nazi occupation policy, has not often been the subject of research by scientists. Its source base has been explored even more rarely. At the same time, the documents from one of the structures of the NSDAP, namely the service the Commissioner of the Fuehrer for the Supervision of the Entire Intellectual and Ideological Schooling and Training of the NSDAP (German: Beauftragter des Führers für die Überwachung der gesamten geistigen und weltanschaulichen Schulung und Erziehung der NSDAP, abbreviated to DBFU) (hereinafter referred to as the Rosenberg Office, in German: Amt Rosenberg or Dienststelle Rosenberg') testify that after the outbreak of the Second World War the importance of activities by the NSDAP services, directed to ensure the ideological component of the Nazi policy towards the occupied territories of Eastern Europe, primarily the USSR within the socalled "struggle against Bolshevism", which in the Third Reich was considered one of the» ideological enemies for National Socialism» along with Jewry and Freemasonry, has increased. As a result, a part of the documents from the Rosenberg Office, who was considered one of the main ideologues of National Socialism and was the head of the Reich Ministry for the Occupied Eastern Territories, serves as a valuable source on the history of Bolshevism research by the employees at the services of Alfred Rosenberg, using the materials, taken out of from the occupied territory of the USSR, first of all, Ukraine and Belarus, as well as attempts to bring this activity into a scientific (and in fact, squasi-scientific) basis, for example, in the work of the so-called «Main Office for Science» (German: Hauptamt Wissenschaft) by the Rosenberg Office.

${ }^{1}$ Today, the use of the latter terms is well established in German scientific literature, although some researchers still consider the terminological distinction to be debatable. 
Analysis of research and publications. The activities of the Rosenberg Office and its structures have long been the subject of research by several Western European historians, primarily German ones but, unfortunately, there are very few complex fundamental publications so far. Among them we should mention the work by R. Bollmus, dedicated directly to the Rosenberg Office and its place in the NSDAP, which has undergone to several reprints [1] and the work by A. Zellhuber, dedicated to the Reich Ministry for the Occupied Eastern Territories [2]. The Rosenberg Office, or its individual employees are also mentioned in works, devoted to individual departments, or in publications on other topics, for example, in publications that cover the life and work of A. Rosenberg himself [3,4]. This is largely due to the fact that German researchers consider the activities of the Rosenberg Office, as a rule, through the prism of research into the personality of A. Rosenberg and his place and significance in the NSDAP, the role of its structures in the internal politics of the NSDAP, as well as in the internal party struggle and competition with other similar structures ${ }^{1}$. It is also worth noting that German researchers generally do not highly appreciate the authority of A. Rosenberg in the ruling circles of the Reich, and the work of the institutions he supervises, both in the party and in general in the politics of the Third Reich during World War II, is considered as such that there was no clear influence and significant results. ${ }^{2}$ The exception is the individual Rosenberg's structures, whose activities were associated with archeology, history and philosophy, support for German literature and art, issues of anti-Semitism propaganda, etc., namely the department "Prehistory and Old History" (German: Amt für Vor- und Frühgeschichte), the main departments "Science" (German: Hauptamt Wissenschaft), "Writing" (or "Literature", German: Hauptamt Schrifttum) at the Rosenberg Office, Higher School (German: Hohe Schule) as conceived by A. Rosenberg as a higher educational institution of the NSDAP [5] and the Institute for the Study of the Jewish Question, founded with it (German: Institut zur Erforschung der Judenfrage) and others, as well as the Special

${ }^{1}$ Among them, for example, the department "Prehistory and Old History" of the Rosenberg Office competed with the wellknown organization "Ahnenerbe" of Reichsfuehrer SS H. Himmler in the field of historical and archaeological research; office "Science" competed with Main Office "Science" at head of political organization NCDAP (German: Reichsorganisationsleiter), as well as there were a number of other competing party educational structures at different levels of NSDAP administration and education. But the main difference in the role and significance of these structures for our study, as well as for the history of Nazi politics in the field of ideology and science in the occupied territory of Eastern Europe, is that some part of the Rosenberg Office units focused on the study of the occupied territories of the USSR and Bolshevism, a source base for which was provided by the ERR, and tried actively to introduce the received information into the educational process not only directly in the Third Reich but into work with political education of civil administration employees in the occupied territories of the USSR, employees of the Wehrmacht.

${ }^{2}$ The indirect evidence of this and of limited possibilities of the Rosenberg Office is the data on its financing, given by R. Bollmus, according to which in 1938 its annual budget amounted just to over one million Reichsmarks, while, for example, the annual budget of the Reich Ministry of Education and Propaganda under the leadership of J. Goebbels between 1933 and 1939 increased from 28 million to 95 million Reichsmarks. 
Command Force of Reichsleiter Alfred Rosenberg (German: Einsatzstab Reichsleiter Rosenberg, hereinafter referred to as the ERR), which during the years of occupation became one of the largest Nazi organizations, engaged into massive plundering of cultural property in the Nazi-occupied countries of Europe [6-14]'. The documents of these structures have so far been used by scientists to a small extent in their historical research, or have not been introduced into scientific circulation at all, while they contain the valuable information on the conduct of the ideological struggle against the USSR and the occupation, and a significant part of German researchers paid little attention namely to this fact.

The purpose of the study is to characterize the documents of the Main Office for Science of the Rosenberg Office and related materials of A. Rosenberg's other structures as the sources on the ideological component in struggle of the Third Reich against Bolshevism and their significance for information or ideological component of the Nazi occupation policy in the occupied territories of Eastern Europe. This presupposes the solution of a number of research tasks, among which is the determination of the storage location for these documents, their completeness and safety, the possibility of access for researchers, disclosure of their content and information potential for use in historical research of the ideological policy by National Socialism in relation to the occupied countries. The introduction of these sources into scientific circulation will expand the base of sources for research on the history of the country in Eastern Europe during World War II, supplement the knowledge of Ukrainian researchers during the occupation of 1941-1944. First of all, those who study the ideology of Nazism - the so-called "struggle against Bolshevism", and the links between National Socialist ideology and science and propaganda.

The scientific novelty of the research lies in the fact that the materials by Rosenberg Office and the documents of the Main Office for Science, in particular, were not the subject of a separate comprehensive scientific examination, therefore, until now, they have not practically been introduced into scientific circulation. They are sometimes used as historical sources in the works of German researchers, who considered, first of all, the place of the Rosenberg Office in the NSDAP system, and its significance for internal party politics. These documents were also not the object of research by Ukrainian scientists for their possible use as historical sources on the history of the ideological component at Nazi policy towards the territories, occupied by them.

Presentation of the main material. The Commissioner of the Fuehrer for the Supervision of the Entire Intellectual and Ideological Schooling and Training of the NSDAP dates back to 1934. Its main task was to control the "implementation of the

${ }^{1}$ The activities by the Einsatzstab Reichsleiter Rosenberg have actively been investigated over the past decades among all the structures that A. Rosenberg established or supervised. You can get acquainted with it in the scientific publications of Patricia Kennedy Grimsted, Ulrike Hartung, Tetiana Sebta, Nataliya Kashevarova, Nazar Gutsul, Serhii Kot, Lyubov Dubrovina and others.

\section{Розділ 4}


National Socialist worldview into all life spheres of the German people" and to prevent "distortions", as well as to supervise the ideological work in the party, including its structures and unions $[15,41]$. Its creation was the result from the desire of Alfred Rosenberg as one of the ideologues for National Socialism and a representative of the ruling circles in the Third Reich to strengthen its position in the NSDAP, to expand its influence in education and training in the party, as the party was closely linked with different levels.

At the beginning, the Rosenberg Office had several divisions that were supposed to be responsible for various thematic areas - education, literature, art, music, history and archeology, ethnography, etc., and which were focused on internal politics and participation in the functioning of the NSDAP' ${ }^{1}$. The number of such units and their structure changed several times throughout the entire period of the Rosenberg Officess existence but the important stage in its history was the beginning of World War II, when activities aimed at ensuring the conduct of the ideological struggle against Bolshevism, including through the use of various materials that were confiscated in the occupied part of the USSR acquired the new content in political studies and propaganda. It was then that a number of departments of the Rosenberg Office joined to this activity, primarily the Main Office for Science, for Superstate Forces (the predecessor of which was the Department for Jewish Affairs and Freemasonry), "Ideological Information", "Prehistory and Old History" and "Folklore and Organization of Festivals" (or "Folklore and Celebration Organization", German: Amt Volkskunde und Feiergestaltung), which were transformed from "departments" into "main offices". In total, their tasks in the Rosenberg Office were much broader than the task of spreading and strengthening the National Socialist ideology and the ideological struggle against Bolshevism. Various ideologies, questions of religion and church, the spread of German culture and historical ties of Germany with other peoples and countries, etc. were studied. But since 1941, the study of Bolshevism as ideology, the implementation of communist postulates into a single large country - in the Soviet Union was recognized as important for waging war, and the active work in the field of science, ideology and propaganda should contribute to the victory of the Third Reich. Therefore, the work of these departments, in general terms, should help to strengthen the ideological convictions of the Germans, especially those ones, who worked in the occupied territories of Europe, also provided for cooperation with various state authorities and administration in the field of culture and propaganda. Therefore, in this regard, the total number of employees at the Rosenberg Office was increased significantly: in February 1939 it employed 156 people (according to other sources 142), and in September 1943 - already 309 people [1, 330-331].

${ }^{1}$ There was a separate structure for foreign policy - the Foreign Office of the NSDAP (German: Außenpolitisches Amt), also established by A. Rosenberg. 
Approximately in 1942 (not earlier than the fall of 1942) or in $1943^{1}$ the Rosenberg Office consisted of the following main divisions (either as independent departments or as divisions of the main offices) [15, 39-40; 16]: the Central office (German: Zentralamt) under the leadership of Gerhard Utikal, who was also the head of the ERR; Main Office "Training Planning"2 (German: Hauptamt Lehrplanung), under the leadership of Helmut Stellrecht, with such departments in its composition: "Education plans development" (German: Amt Lehrplangestaltung), head Fritz Sotke, "Aids for party training" (German: Amt Parteiamtliche Lehrmittel), head Hans-Georg Otto, "The Imperial Workers> Society for the Training of the Entire [Party] Movement" (German: Amt Reichsarbeitsgemeinschaft zur Schulung der gesamten Bewegung), head Fritz Sotke, Wehrmacht Training Department (German: Amt Werhmachtsschulung), head Fritz Sotke; main office "Writing", head Bernhard Payr, with the department "Central administration" (German: Amt Zentralrektorat) in its composition, the head of the latter was also Bernhard Payr; Main Office for Science, head Walter Groß, with such departments as "Prehistory and Old History", head Hans Reinerth, "Folklore and Organization of Festivals", head Hans Strobel; Main Office "World outlook information" (or "Ideological information", German: Hauptamt Weltanschauliche Information), head Hans Hagemeyer; Main Office "Care for the arts" (or "Support for the arts") (German: Hauptamt Kunstpflege), head Walter Groß, with such departments in its composition: "Dramaturgy and theatrical arts" (German: Amt Dramaturgie und darstellende Kunst), head Karl Künkler, "Fine Arts" (German: Amt Bildende Kunst), head Robert Scholz, "Music» (German: Amt Musik), head Herbert Gerigk; department "Special Tasks" (German: Amt Sonderaufgaben), head Otto Schmidt, Press Office (German: Presseamt), head Otto Biedermann, Administrative Office (German: Verwaltungsamt), head Carl Kerksiek, and also a separate training center (German: Schulungshaus) under the leadership of Walter Knoop, which operated under the foreign policy department of the NSDAP [16, 89], and the Higher School Development Office (German: Aufbauamt der Hohen Schule).

One of the central places among them was occupied by the Main Office for Science, which was originally a separate department, since 1936 to 1938 - the central service "Science", since 1938 to 1941 already a department for Science, and since 1941 the Main Office for Science. At the head of it until 1941 was Alfred Baeumler ${ }^{3}$, one of the ideologues of the NSDAP, who in this position significantly contributed to the ties of the Rosenberg Office with German universities. Heinrich Härtle succeeded him in

${ }^{1}$ We could not find any accurate information about the date of this reorganization of the Rosenberg Office.

${ }^{2}$ Hereinafter, the translation of the names is approximate but close to the meaning of the name.

${ }^{3}$ Alfred Baeumler (1887-1968) was a German philosopher and educator. He was a professor at the University of Berlin, actively used the ideas of the philosopher Nietzsche in the promotion of National Socialism.

\section{Розділ 4}


$1941^{1}$ as an acting manager [17, 31]. Since mid-August 1942, the office was headed by Walter $\mathrm{Groß}^{2}$, and $\mathrm{H}$. Härtle became his deputy. Its structure included a number of smaller units. In 1940, its structure included the following main services and services: "Philosophy" (German: Hauptstelle Philosophie), "Humanities” (German: Stelle Geisteswisenschaften), "Scientific Information" (German: Hauptstelle Wissenschaftliche Information), which was to observe the trends in science in Germany and abroad, "Scientific Societies and Congresses" (German: Stelle Wissenschaftlichen Gesellschaften und Kongresse), "Science Abroad" (German: Stelle Wissenschaft des Auslandes), "Scientific Catalogue" (German: Stelle Wissenschaftskartei) and a separate reference service that cooperated with the press, including information on scientific events, organized by the Main Office for Science [16, 42]. These units were also engaged in compiling the scientific bibliographies, including new publications in Germany and abroad, maintaining a personal file on scientists, which should also contain the personal characteristics, were engaged in the preparation of translations, analytical reports and more. In December 1941, the Natural Sciences Service (German: Stelle Naturwissenschaften) was added to the Main Office for Science [16, 81], and as of 1943 the departments "Prehistory and Old History" and "Folklore and Organization of Festivals", were structurally transferred to its structure [15, 70-72]. This department was engaged into philosophy, history, pedagogy, as well as the National Socialist or "Aryan" worldview, respectively, among this, its tasks included the observation, assessment and support of scientific life in German higher education institutions and outside them from the point of view of national socialist worldview, observation on the activities of German societies; supervision and support of scientific youth; cooperation with the German Research Society (German: Deutsche Forschungsgemeinschaft) influence on the conduct of scientific events and participation in them;

${ }^{1}$ Heinrich Härtle (1909-1986) was a Nazi functionary and publicist. Since 1927 he was a member of the NSDAP, and in 1933-1936 he studied at the German Higher School of Politics (German: Deutsche Hochschule für Politik). In 1936-1939 he was the head at one of the departments within the Main Training Department of the German Labor Front (Hauptschulungsamt der Deutschen Arbeitsfront). Since 1939 - employee of the Commissioner of the Fuehrer for the Supervision of the Entire Intellectual and Ideological Schooling and Training of the NSDAP. He was considered an expert on Marxist-Leninist ideology, a connoisseur of Bolshevism, so in 1944 he moved from the Main Office for Science to the Main Office of the Superpowers of the Rosenberg Office, where he headed the so-called "Arbeitsgemeinschaft zur Erforschung der bolschewistischen Weltgefahr." He prepared a number of works of propaganda content on the ideology of Bolshevism and its scientific principles, the most famous of which was the work "Ideological Foundations of Bolshevism" (German: Die ideologischen Grundlagen des Bolschewismus) (1944), which he republished in 1955 under the pseudonym "Helmut Steinberg" entitled "Marxism, Leninism, Stalinism. The Spiritual Offensive of the East" (German: Marxismus, Leninismus, Stalinismus. Der geistige Angriff des Ostens). This work, as well as the book that was published in 1969 and devoted to A. Rosenberg, acquired the negative impressions in German society.

${ }^{2}$ Walter Groß (1904-1945) was a German politician, physician, known for his commitment to so-called "racial purity" and author of a number of journalistic works on racial theory and anti-Semitism. Member of the NSDAP since 1925, founder of the NSDAP Racial Policy Department (1933), and member of the Reichstag since 1936. In collaboration with A. Rosenberg, he planned to open the research institute of biology and racial doctrine ("Institut Biologie und Rassenkunde") at the NSDAP Higher School. 
checking their products; assessment of individuals in science, consultative work with party services; providing with information about scientific events for A. Rosenberg's party periodical and series publications "Völkischer Beobachter", "NS-Parteikorrespondenz"; press relations; monitoring the development of science abroad [16, 41]. But in practice, the directions of his work sometimes overlapped with the activities by other divisions of the Rosenberg Office, first of all, with the above-mentioned department of "Superstate Forces", into which H. Härtle moved in 1944, at the same time heading the Working Society for the Study of the World Bolshevik Threat.

Most of the documents at the Main Office for Science are preserved in the German Federal Archives (German: Bundesarchiv), in Berlin, in NS 15 fond ("Der Beauftragte des Führers für die Überwachung der gesamten geistigen und weltanschaulichen Schulung und Erziehung der NSDAP"). Here is the largest integral set of his documents - at least 96 files, namely: 104, 106a, 107-109, 112-115, 120, 122-123, 191$251,288-293,296-303,307-316,330$. The materials of the department can be found in several other fonds of the Federal Archive, primarily in several files of NS 8 fond ("Kanzlei Rosenberg", English:"Rosenberg's Chancellery"), where most documents of the department are concentrated, first of all, on files nos. 228, 229, 240, 241, as well as in a scattered state in various files s in NS 30 fond ("Einsatzstab Reichsleiter Rosenberg"). Basically, these are the correspondence materials and materials in copies that were sent out for information. Materials of the Main Office for Science are also stored in archives of other countries all over the world as a part of complexes for documents of Nazi origin, at one time they were exported from the territory of post-war Germany, for example, as a part of the collections at the Institute for Jewish Research, better known as "VIVO" (thanks to the abbreviation of the previous name) [18], the same collection in the form of copies since 2017 is presented at the United States Holocaust Memorial Museum [19]. Certain documents can be found in the Central State Archive of Supreme Bodies of Power and Government of Ukraine in Kyiv, in particular, among documents of 3676 fond ("Special Command Force of the Imperial Leader of Rosenberg for the Occupied Eastern Territories") [20].' A part of documents from the Main Office for Science was digitized, namely all of its documents that are a part of the above-mentioned NS 8 fond [21] and individual documents - in NS 15 [22] and NS 30 [23] fonds of the Federal Archives of Germany, as well as a part of 3676 fond in Central State Archive of Supreme Bodies of Power and Government of Ukraine. You can get acquainted with them on the archival portals of these two archives, these documents are in the public domain: NS 15 and NS 30 fonds are in a separate section

${ }^{1}$ It should be noted that a significant part of these documents is duplicated in the collections, stored in these archives, primarily because the documents that fell into the American zone of occupation were exported to the USA, where some of them were microfilmed and returned to Germany in the 1960-ies. But the history of the displacements of these documents, as well as the complete picture of the location of all documents from the Main Office for Science, is the topic of a separate archival research.

\section{Розділ 4}


of the digitized collections of the Federal Archives ${ }^{1}$, and materials from 3676 fond on a separate page on the website by Central State Archive of Supreme Bodies of Power and Government of Ukraine in Kyiv, dedicated to the documents by the ERR [24].

The materials of the Main Office for Science are mainly represented by the following groups of documents: service materials on the internal organization of the office, its subordination, structure and functions, both of the entire office and its divisions; documents of personal origin, first of all, documents of employees, materials in relation to other persons (representatives of science and education in Germany), who were of interest for the work of the department, documents on workshops about education and science, not only in the NSDAP but also in relation to education and science at higher educational institutions in Germany. Another large part is made up of thematic materials, prepared for further use in training and propaganda, in particular, memos, projects; thematic filings of press materials, among them the publications by employees at the Main Office for Science, for example, on the relevance of science in war, and articles on various periodicals, published not only directly in the Third Reich but also in the territories, occupied by the Nazis. A separate large group should be allocated to correspondence, both internal - with other structures of the Rosenberg Office, and external - with other NSDAP services, with universities, scientific societies, government bodies, primarily on the organization of interdepartmental cooperation, exchange of printed materials.

All these documents testify to a wide range of tasks at the Main Office for Science, which A. Rosenberg set. Among them, for example, there was the control in the field of university science in the form of checking the scientific and pedagogical activities of higher educational institutions, including checking manuscripts of scientific works by higher school teachers for their ideological background, preparing and publishing a number of serial publications on the topic of ideology in science and training, published at the expense of the NSDAP and distributed among its members, the regular organization and conduct of a number of lectures, as well as the sending the representatives of the Rosenberg Office as liaisons and observers to party districts throughout Germany. It should also be noted that, to a large extent, a number of tasks for the Main Office for Science and partially - its policy in the field of science and ideology during 1942-1943 was defined by the aforementioned Heinrich Härtle. So, in a memo, dd. March 4, 1943, H. Härtle, as deputy head of the Main Office for Science, proposed to involve all scientific institutions and forces to perform the military tasks in order to "strengthen the spiritual resistance of German people" $[17,71]$, which was also influenced by the order of Adolf Hitler, dd. June 15, 1942 on the need to attract all available forces in the public interest, first of all, they contribute to the combined use of German scientific research in the struggle and their provision

1See: https://www.bundesarchiv.de/DE/Navigation/Finden/Digitalisierte-Bestaende/digitalisierte-bestaende.html 
for the set goals [17, 30]. According to the tasks of the Office, determined by H. Härtle, it was supposed to entrust German scientists and teachers with the work to collect various materials, to give the public educational lectures on the topic of ideology and topics, important for waging war, at all significant cultural centers in cooperation with the state, primarily with the Ministry of Propaganda of the Third Reich and the Reich Ministry of Foreign Affairs, with other structures of the NSDAP itself, Wehrmacht services, scientific institutions, etc.; publication of materials about public events, organized with participation of the Office [17, 9], organization of work in camps of members in the Imperial Union of High School Teachers (or the National Socialist Imperial Union of Associate Professors) (German: Nationalsozialistischer Deutscher Dozentenbund), lecturing during educational events in the Wehrmacht. It was supposed to use radio, scientific periodicals and serials; reformatting the thematic work plans of research organizations, plans for preparation of dissertations at universities (in accordance with military topics), selection of the most ideological teachers to work with students. [17, 165-167]

The greatest scientific interest for our study is the work by those divisions of the Main Office for Science that were in some or other way associated with Nazi policy in the occupied territory of the USSR, and those documents that contained the relevant information. Their number is not very significant against the background of the above materials by the Office, related to various issues of internal life in the Reich but they can act as a new and interesting source for scientific countries of Eastern Europe, first of all, the countries of the post-Soviet space. Basically, these are materials of H. Härtle, who, as the deputy head of the Office after 1941, assigned the important role to collect the information about Soviet science to German scientists and teachers - they could make a trip to the occupied territories of the USSR with a separate scientific assignment $[17,74-78]^{1}$, and also planned even to attract German students (optionally) during the holidays to work in the occupied territory of the USSR. ${ }^{2}$ The materials from various public events and meetings, organized by the Rosenberg Office and its Main Office for Science, where it was supposed to give lectures on various scientific problems, related to the Soviet Union and in which the so-called "experts of the East" took part, where the term "East" meant the occupied territories of the USSR, are also interesting. First of all, they were historians, archaeologists, specialists in Slavic studies, economists, psychologists, etc. But at the same time, for exam-

${ }^{1}$ They could visit the occupied territories of the USSR as employees of Special Staffs at the Main Office for Science under the ERR, which is discussed in more detail later in the publication.

${ }^{2}$ This task was accomplished: in 1942-1943, several groups of German students visited the occupied territory of the USSR and were instructed, first of all, to compile a Soviet bibliography on individual topics, as well as to prepare a report on the results of their work. Some of these reports are stored in 3676 fond in the Central State Archive of Supreme Bodies of Power and Government of Ukraine in Kyiv, Ukraine.

\section{Розділ 4}


ple, the program of so-called "Eastern meeting" of German scientists and teachers (or meeting on Eastern issues but in fact - in relation to the occupied countries of Eastern Europe), which took place since 24 to 27 March 1942 in Berlin, in the building of the Reich Ministry of Labor in the presence of Alfred Rosenberg himself and the head of the Imperial Union of High School Teachers testify to the thematic content of such public, as well as learning and educational events, and what exactly was meant by the term "science" for the occupied eastern territories. Among his speakers were the employees at the Reich Ministry of the Occupied Eastern Territories (German: Reichsministerium für die besetzten Ostgebiete), which carried out the administrative management in the occupied territory of the USSR, Rosenberg Office ${ }^{1}$, a number of scientific and educational societies, associations and organizations. Thus, according to the program of the meeting, the head of the policy department at the Ministry for the Occupied Eastern Territories Georg Leibbrandt made the report, entitled "Political Tasks of Science in the Occupied Eastern Territories", the head of the general policy department at the Ministry Otto Bräutigam made the report, entitled "Ownership rights in the Occupied Eastern Territories", Gerhard von Mende, expert on the peoples of the Caucasus, made the report, entitled "Ethnic groups in the Occupied Eastern Territories", Heinrich Härtle, head of the Main Office for Science "Bolshevism's policy on science", and German historian Hans Koch - "Psychological Consequences of Bolshevism". Other reports focused on the challenges of agriculture, health care, and even chemistry and physics in the East [17, 2, 19-24]. Another striking example is the work by $\mathrm{H}$. Härtle himself, which he published in serial party publications, for example, the work "Bolshevism and Science".

But even more valuable for research is a group of materials, related to the activities of so-called Special Staff Science (German: "Sonderstab Wissenschaft"), which since 1942 has represented the interests of the Main Office for Science [25, 225] in the occupied territories of the Soviet Union [26] ${ }^{2}$, and whose documents are closely related to the materials of the Main Office for Science ${ }^{3}$. There were up to 15 different

${ }^{1}$ The same individuals often held several combined positions in different structures of Alfred Rosenberg, such as the Ministry of the Occupied Eastern Territories and the Rosenberg Office.

${ }^{2}$ In autumn of 1941, before Special Staff "Science" began working in the occupied territory of the USSR, these functions in occupied Ukraine were performed by the group "Science", led by Wolfgang von Franque, who was the first one to survey the scientific institutions in city Kyiv shortly after its occupation by German troops. The documents of this group can be found as a part of the documents from 3676 fond in the Central State Archive of Supreme Bodies of Power and Government of Ukraine in Kyiv, and they are also partially published in the documentary publication, dedicated to the history of the National Academy of Sciences of Ukraine. See: Iсторія Національної академії наук України (1941-1945): Частина 1. Документи і матеріали / редкол.: 0.С. Онишенко (відn. ред.) та ін. К., 2007. 808 с. Режим достуnу: http://resource.history.org.ua/item/0013046

${ }^{3}$ See the details on the work of Special Staff "Science" in the occupied territory of the USSR in: Kashevarova, N. (2014). Dialnist Operatyvnoho shtabu Rozenberga z vyvchennia natsystamy «skhidnoho prostoru» (1940-1945) [The ERR activities on the nazi Ostraum study (1940-1945)]. Pt. 1: Dzhereloznavche doslidzhennia [Source Study], pp. 225-237. 
Special Staffs under the ERR, each of which was responsible for a separate thematic area and had a corresponding name, for example, Science, Fine Arts, Old History (or Archeology), Folklore, Music, Religious studies, etc. Each Special Staff was formed from employees of the relevant departments of the Rosenberg Service and invited the specialists from the relevant industry. Thus, Special Staff "Science" was formed by the Main Office for Science, Special Staff "Fine Art" - by the Main Office "Fine Art", etc. But administratively, the Special Staff as a structure was assigned to the ERR, its personnel were subordinate to the leadership of the main working group at the ERR, within which area of responsibility an employee of the special staffs performed his work. This was due to the fact that in order to carry out work in the territories, occupied by the Nazis, German specialists, who were not military, had to be attached to a certain structure, officially worked in the East. Unlike other Nazi civilian structures, the ERR had the right to work not only in the occupied territory, which was a part of the civil administration control zone but also in the territory under military control, which significantly expanded the capabilities of employees and provided the Rosenberg Office with materials from the occupied eastern territories. Each employee of Special Staff received a separate work order, which clearly defined his/her tasks and mentioned the main working group of ERR, for example, the Main Working Group "Ukraine", the Main Working Group "Ostland", where the employee was sent, as well as the terms of order execution. At the same time, he/she not only had to fulfill the requests of the Main Office for Science, as well as the Rosenberg Office in general, the Reich Ministry for the Occupied Eastern Territories but also could collect the information in accordance with his/her own scientific interests. Special Staff "Science" was one of special staffs that actively worked in the occupied territory of the USSR since the beginning of 1942. It should also be mentioned that, in addition to Special Staff "Science", there were the special staffs "Old History" and "Folk Studies" in the occupied territory of the USSR, which were also established by appropriate departments and which, as it has already been mentioned, were within the Main Office "Science" in 1943. But the active work of these two structures in the occupied territory of the USSR falls mainly to 1942 and deserves a separate in-depth study, therefore, in our publication, the work of these two special staffs is not considered.

The head of the Special Staff "Science" was the same H. Härtle but the task of this Special Staff was broader than the task of the Main Office for Science, including thematically, and also had a direct practical significance. The staff of the Special Staff was formed from the staff of the Main Office for Science and the Rosenberg Office but a significant part of it was made up of German researchers that represented various institutions in Germany, primarily universities, research institutions and societies, and expressed a desire to work in the East. ${ }^{1}$ Among them there were the fol-

${ }^{1}$ The term "East" here means the occupied territory of the USSR, not only Ukraine, Belarus and a part of Russia but also a number of Baltic countries - Estonia, Latvia and Lithuania, which became a part of the USSR in 1940.

\section{Розділ 4}


lowing German employees (not counting the invited employees - representatives of the local intellectuals) Hans Braun, assistant at the Main Office for Science of Rosenberg Office, head of Special Staff "Science" in Ukraine, philosopher Hermann Noack, Rudolf Proksch, Rudolf Thiele, psychologist and educator Gustaf (Gustav) Deuchler, geologist [L.] Thomson, physicist Harald Fischer, economist Walter Thoms ${ }^{1}$, spouses of physicians Fritz and Leonore Puschke ${ }^{2}$, microbiologist Schwartz, economist PeterHeinz Seraphim, scientist in the field of natural sciences, teacher, head of the branch of the Higher School from racial studies and biology Werner Hüttig, Rudolf Gippius, lawyer, specialist in Magdeburg law Franz Klein-Bruckschwaiger et al. (totally in average 13 people). Separately, it should be noted that the Special Staff in Ukraine in 1942 included a group of students from Faculty of Foreign Policy at Berlin University, a branch of the Soviet Union Studies, under the leadership of Bernhard Siebler [27, 264-265; 28, 2-3; 29; 30, 105-116, 170-179; 222, 7-10, 248-250], consisting of: Ernst Zahn, Adolph Klein, Ingrid Christoph, Ingeborg Augustin, Hella Spahn, and Miss Gogarten³.

The tasks and powers for Special Staff "Science" were defined by several documents, dd. late December 1941 and 1942, in particular, several instructions and a special memo for employees [32, 15-27; 25, 225-226]. Among its main tasks according to the order of the Administration Office of the ERR (German: Stabsführung), dd. September 24, 1942, there were as it follows: 1) to ensure the safety of scientific institutions and scientific materials in the occupied territories to the extent that they represent Soviet science and if they can be useful to German science; 2 ) to evaluate the confiscated scientific materials (according to documents literally «secured», in German "sichergestellte"); 3) involvement of scientists with separate scientific assignments. According to a separate instruction, dd. December 23, 1941, the special attention should be paid to universities and other institutions of higher education, scientific academies and institutes, research societies, unions, experimental enterprises, and laboratories. The staff of the special staffs had personally to visit such institutions, to keep their records in the prescribed form [32, 16]. This included their review, determination of physical condition, scientific value, possibilities of use both in the occupied territories and in the Third Reich [25, 225-226]. But at the same time,

'See more: Кашеварова Н. (2020). Економіко-статистичні дослідження промислових регіонів України німецькими дослідниками під час окупації (1942-1943). In: Наукові праці Національної бібліотеки України імені В. І. Вернадського. Bun. 58.SS.394-410. Режим достуny: http://np.nbuv.gov.ua/doc/npnbuimviv_2020_58_31

2 See more: Schmidt M., Gutsul N., Kleinmanns J. (2017). Medizin und Politik in der NS-Zeit am Beispiel der Ärzte des "Sonderkommandos Künsberg" und des "Einsatzstabs Reichsleiter Rosenberg". In: Neue Forschungen zur Medizingeschichte Beiträge des "Rheinischen Kreises der Medizinhistoriker". Kassel: Kassel University Press GmbH, S. 103-128; Кашеварова H. (2019). Радянська система охорони здоров'я очима німецьких спеціалістів Оперативного штабу Розенберга / Н. Кашеварова. In: Сторінки воєнної історіїУкраїни. Вun. 22. SS.176-191. Режим достуny: http://resource.history.org.ua/publ/Sviur_2019_22_10

${ }^{3}$ The first name is not identified. 
the employees of the special staffs did not have the right to confiscate these collections - this should only be carried out by the local units of the ERR - the main working groups and working groups. In addition, the employees of the special staffs, who was officially called "researchers", had to prepare the separate reports on their work in the occupied territories and intelligence on specific topics in accordance with their specialization. The reports by the employees of the Special Staff Science were made in several copies and sent to the Main Office for Science, the Administration Office of the ERR in Berlin and to the main working group, where the employee of the Special Staff Science worked. The issued results of the work were sent not only to the Rosenberg Office but could also be transferred to other institutions in the Reich for further use in their work. Among the materials of the ERR, such results are presented as "papers" (German: "Ausarbeitungen"). There was a separate thematic plan for the employees of Special Staff "Science", according to which they had to prepare the "papers". According to this plan, the special attention should be paid to the peculiarities of Soviet science, how free it is from Marxist-Leninist ideology, the importance of dialectical materialism for certain branches of science, ways and means of influencing the Soviet leadership on science, the contribution of Soviet science to strengthening Marxist-Leninist and Stalinist ideology, the manifestation of the general line of the party in various fields of science (except history), the tasks and organization of trade unions of professors and associate professors, scientific organizations and unions, state support for scientific research. The particular attention was paid to the study on Soviet scientific intellectuals.

The materials for the Main Office for Science are stored in the above-mentioned fonds of the Federal Archive of Germany and the Central State Archive of Supreme Bodies of Power and Government of Ukraine in Kyiv of Ukraine, mainly among the materials of the ERR. So, among the materials of NS 30 fond at Federal Archives of Germany, the documents of the Special Staff Science are concentrated in files No. 84-91, 169-170, 225, etc., basically, these are the materials of various contents, first of all job reports and propaganda articles, prepared by the employees of the Special Staff Science. Its documents are in NS 8 fond but there are very few of them and they are scattered in various files. The documents of the Special Staff Science and the Main Office for Science are stored in the Central State Archive of Supreme Bodies of Power and Government of Ukraine in Kyiv in large numbers among the documents of the ERR in 3676 fond, as well as in the collection of the microcopy documents KMF-8 (files $85,272,275$ of the of the inventory \#1). But it should be noted that the latter ones are the copies of documents that are now stored in the above fonds in the Federal Archives in Berlin.

The important part of the documents for the Main Office for Science consists of documents of personal origin - personal files of research workers, official documents on work assignments, business trips that provide with information about the

\section{Розділ 4}


branches of science that the employee represented; chronological reports and thematic reports of employees about the work - the latter ones are especially informational valuable due to the fact that they contain the data on scientific institutions of Ukraine while in occupation during the Second World War, including the Crimea, as well as the final summary chronological reports of the Special Staff "Science" itself. The personal files of most staff at the Special Staff Science, as well as several students from the foreign faculty at University of Berlin, who worked in the East during the holidays, can be found in the Central State Archive of Supreme Bodies of Power and Government of Ukraine in Kyiv, Ukraine, in the mentioned 3676 fond, in folders 89 $92,96,99,102,103,104$ of the of the inventory \# 1, and in files 222 and 223 of the inventory \# 2.

Conclusions. The Main Office for Science was one of the main departments of the Rosenberg Service in the structure of the NSDAP, among the main tasks of which was the supervision of scientific life in German higher education institutions and outside them from the point of view of the National Socialist worldview, checking their products, monitoring the activities of German societies, supporting the scientific youth, organizing and conducting the scientific events, consulting various services of the NSDAP and other institutions, working with the press, etc. With the outbreak of World War II, especially when the Nazis occupied the territory of the Soviet Union, the role of collecting and processing scientific information about the Soviet Union in the activities of the Main Office for Science has significantly increased. For the prompt receipt of various materials of scientific content from the occupied territories of the USSR, it actively cooperated with the ERR and the Special Staff Science became the representative of its interests in the ERR. As a result of the activities by these two structures, a large set of documents was formed, a significant part of which is now stored in Federal Archives of Germany and in the Central State Archive of Supreme Bodies of Power and Government of Ukraine in Kyiv, Ukraine. Most of these documents have been digitized and are in the public domain. They serve as the historical sources not only for researchers on the ideology of National Socialism and the history of the NSDAP but also for researchers on the history of World War II, primarily the history of the countries of Eastern Europe and the Soviet Union, since they contain a lot of information that has not yet been known (or was little known) to researchers of post-Soviet countries, namely, data on the movement of scientific values during the war, the state of scientific and their collections that remained in the occupation, the Nazi vision on achievements of Soviet science and its scientific potential, the possibilities of their use for the scientific needs of the Third Reich and for operational use within promotional or practical purposes.

At the same time, the question about scientific nature of such activities, primarily in the work of the Special Staff Science, the degree of influence of Nazi ideology on them remains open. But, on the other hand, these documents demonstrate 
the vision on importance of science in the Third Reich, its connection with education, political education. They are a testament to how Nazi ideology shaped the demand for research and influenced its results. In these terms, the activities of the Main Office for Science of the Rosenberg Office, as well as a number of other structures, deserve further in-depth study by historians of World War II, as well as its links with other institutions and organizations of the Third Reich that during the war and Nazi occupation were the leaders of National Socialist ideology and were associated with the Nazi policy toward the countries they occupied.

\section{References}

1. Bollmus R. Das Amt Rosenberg und seine Gegner: Studien zum Machtkampf im nationalsozialistischen Herrschaftssystem. München: R. Oldenburg Verlag, 2006. https://doi. org/10.1524/9783486595543 [In German].

2. Zellhuber A."Unsere Verwaltung treibt einer Katastrophe zu ...." Das Reichsministerium für die besetzten Ostgebiete und die deutsche Besatzungsherrschaft in der Sowjetunion 1941-1945. München: Ernst Vögel Verlag, 2006. [In German].

3. Piper E. Alfred Rosenberg: Hitlers Chefideologe. München: Karl Blessing Verlag, 2005. [In German].

4. Cecil R. The Myth of the Master Race: Alfred Rosenberg and Nazi Ideology. New York: Dodd Mead \& Company, 1973. https://doi.org/10.1017/50084255900019045

5. Auf dem Wege zur "Alternativ-Universität". Die "Hohe Schule" Alfred Rosenbergs und die "Wissenschaftsarbeit" der NSV in Marburg (1994). Klio und die Nationalsozialisten: Gesammelte Schriften zur Wissenschafts- und Rezeptionsgeschichte Volker Losemann I herausgegeben von Claudia Deglau, Patrick Reinard und Kai Ruffing. Wiesbaden: Harrassowitz Verlag, 2017, pp. 77-100. https://doi.org/10.2307/j.ctv11qdvs0 [In German].

6. Collins D. \& Rothfeder H. The Einsatzstab Reichsleiter Rosenberg and the Looting of Jewish and Masonic Libraries during World War II. The Journal of Library History (1974-1987), 1983, vol. 18, No. 1, pp. 21-36.

7. Cultural Plunder by the Einsatstab Reichsleiter Rosenberg. Retrieved from: https://www.errproject.org/

8. Grimsted P. K. Reconstructing the Record of Nazi cultural Plunder. A Survey of the Dispersed Archives of the Einsatzstab Reichsleiter Rosenberg (ERR). Amsterdam: IISH, 2011.

9. Grimsted P. K. Trophies of War and Empire:The Archival Heritage of Ukraine, World War II, and the International Politics of Restitution. Cambridge, MA: Harvard University Press for Ukrainian Research Institute, 2001.

10. Gutsul N. (2013). Der Einsatzstab Reichsleiter Rosenberg und seine Tatigkeit in der Ukraine (1941-1944). Inaugural-Dissertation zur Erlangung des Doktorgrades ... Gießen. Verfügbar unter: http://geb.uni-giessen.de/geb/volltexte/2014/11002/pdf/GutsulNazarii_2013_07_02.pdf [In German].

\section{Розділ 4}


11. Hartung U. Verschleppt und verschollen: eine Dokumentation deutscher, sowjetischer und amerikanischer Akten zum NS-Kunstraub in der Sowjetunion (1941-1948). Bremen: Edition Temmen, 2000. [In German].

12. Kashevarova N. H. Dialnist Operatyvnoho shtabu Rozenberga z vyvchennia natsystamy «skhidnoho prostoru» (1940-1945) [The ERR activities on the nazi Ostraum study (1940-1945)]. Pt. 1: Dzhereloznavche doslidzhennia [Source Study], Pt. 2: Dokumenty [Documents]. Kyiv: Instytut istorii Ukrainy, 2014. [In Ukrainian, in German].

13. Sebta T. Operatyvnyi shtab reikhsliaitera Rosenberga ta yoho bibliotechna diialnist v Ukraini: dzhereloznavchyi analiz. Biblioteky Kyieva u period natsystskoi okupatsii (1941-1943) (pp. 114-148). Kyiv, 2004. [In Ukrainian].

14. Zinich M. Pokhishchennye sokrovishcha: vyvoz natsystami rossijskikh kulturnykh tsennostej. Moskow, 2003. [In Russian].

15. Bundesarchiv Berlin, NS 8/229. [In German].

16. Ibid., NS 8/228. [In German].

17. Ibid., NS 8/241. [In German].

18. Hauptampt Wissenschaft (Berlin) / Guide to the YIVO Archives. Retrieved from: http://yivoarchives.org/index.php? $\mathrm{p}=$ collections/controlcard\&id=32596.

19. Hauptamt Wissenschaft (RG 216) / The United States Holocaust Memorial Museum. Retrieved from: https://collections.ushmm.org/search/catalog/irn559684

20. Kashevarova N. G., Maloletova N. I. Deiatelnost Operativnogo shtaba reikhsljaitera Rosenberga v okkupirovannoj Evrope v period Vtoroj myrovoj vojny: spravochnykukazatel arkhivnykh dokumentov iz kievskykh sobranyj [Activities of the Einsatzstab Reichsleiter Rosenberg in occupied Europe] / NAN Ukrainy; Natsionalnaja biblioteka Ukrainy im. V.I.Vernadskoho [i dr.]. Kyiv, 2006. [In Russian].

21. NS 8. Kanzlei Rosenberg / Bundesarchiv. Verfügbar unter: https://invenio.bundesarchiv.de/basys2-invenio/direktlink/47f30320-f947-4edd-8049-f3fb8b010675/ [In German].

22. NS 15. Der Beauftragte des Führers für die Überwachung der gesamten geistigen und weltanschaulichen Schulung und Erziehung der NSDAP / Bundesarchiv. Verfügbar unter: https://invenio.bundesarchiv.de/basys2-invenio/direktlink/9d5b75da-4a87-4d3086a3-8e542c307333/ [In German].

23. NS 30. Einsatzstab Reichsleiter Rosenberg NSDAP / Bundesarchiv. Verfügbar unter: https://invenio.bundesarchiv.de/basys2-invenio/direktlink/7ac6d63f-7cf5-40b2a375-dd93c010a349/ [In German].

24. Kollektsiia dokumentov Operativnogo shtaba reikhsliaitera Rosenberga [Records of the Einsatzstab Reichsleiter Rosenberg] / Tsentralnyi derzhavnyi arkhiv vyshchykh orhaniv vlady ta upravlinnia Ukrainy [Central State Archives of Supreme Bodies of Power and Government of Ukraine]. Retrieved from: http://err.tsdavo.gov.ua/ [In Russian, in German].

25. Fond 3676, Inventory 1, Unit 141. Tsentralnyi derzhavnyi arkhiv vyshchykh orhaniv vlady ta upravlinnia Ukrainy [Central State Archives of Supreme Bodies of Power and Government of Ukraine]. [In German]. 
26. Kashevarova N. G. Dejatelnost sondershtaba "Nauka" Operativnogo shtaba reikhsljaitera Rosenberga po konfyskatsii tsennostej nauchnykh uchrezhdenij Ukrainy (1941-1943 gg.). Biblioteki natsionalnykh akademyj nauk: problemy funktsionirovanija, tendentsii razvitja, 2005, iss. 3, pp. 298-316. [In Russian].

27. Fond 3676, Inventory 1, Unit 215. Tsentralnyi derzhavnyi arkhiv vyshchykh orhaniv vlady ta upravlinnia Ukrainy [Central State Archives of Supreme Bodies of Power and Government of Ukraine]. [In German].

28. Unit 226. Ibid. [In German].

29. Fond KMF-8, Inventory 1, Unit 275, Roll 94. Ibid. [In German].

30. Fond 3676, Inventory 1, Unit 102. Ibid. [In German].

31. Fond 3676, Inventory 1, Unit 222. Ibid. [In German].

32. BArch, NS 30/169. [In German].

\section{Наталія Григорівна Кашеварова,}

кандидат історичних наук,

старший науковий співробітник

відділу спечіальних галузей історичної науки

таелектронних інформаційних ресурсів

Інституту історії України НАН України

ORCID: 0000-0003-2426-0440

e-mail: nataliya.kashevarova@gmail.com

Документи Головного відомства «Наука» Служби Розенберга як джерела щодо ідеологічної складової політики нацистів на окупованій території Східної Європи під час Другої світової війни

Мета роботи: охарактеризувати документи Головного відомства «Наука» Уповноваженого фюрера у справі нагляду за загальним духовним і світоглядним навчанням та вихованням у НСДАП та пов'язані з ними матеріали інших структур А. Розенберга як джерела щодо ідеологічної складової боротьби Третього райху проти більшовизму та розкрити їхнє значення для інформаційної або ідеологічної складової окупаційної політики нацистів на окупованих територіях Східної Європи. Методологію дослідження складають історико-архівознавчий, історикопорівняльний методи, а також методи джерелознавчого аналізу. Наукова новизна визначається тим, що матеріали Служби Розенберга, зокрема документи Головного відомства «Наука», досі не були об'єктом окремого комплексного наукового архівознавчого та джерелознавчого розгляду на предмет їх можливого використання як історичних джерел з історії ідеологічної складової нацистської політики щодо окупованих ними територій, нацистського бачення зв'язку науки та ідеології, участі співробітників Головного відомства «Наука» в так званій «ідейній боротьбі» проти більшовизму, збирання наукової інформації на окупованій території країн Східної Європи, зокрема СРСР. Хоча ці документи знайомі німецьким дослідникам, але останні використовували їх як джерела для визначення місця Служби Розенберга 
в системі НСДАП та її значення для внутрішньої партійної політики у Третьому райху. Висновки. Здійснений аналіз документів Головного відомства «Наука» Служби Розенберга дозволяє дійти висновків, що низка його документів за 1942-1945рр., а також пов'язані з ними документи зондерштабу «Наука», який представляв інтереси відомства при Оперативному штабі Розенберга, містять цікаву і цінну інформацію не лише щодо зв'язку націонал-соціалістичної ідеології та науки, а й щодо збирання і опрацювання різноманітної інформації про стан науки в Радянському Союзі, передусім матеріалів наукового змісту, зведених даних про стан радянських наукових установ під час нацистської окупації тощо. Ця інформація досі була мало відома або взагалі не запроваджена до наукового обігу, але вона може стати в нагоді дослідникам історії Другої світової війни.

Ключові слова: Друга світова війна, Головне відомство «Наука» Уповноваженого фюрера у справі нагляду за загальним духовним і світоглядним навчанням та вихованням у НСДАП, зондерштаб «Наука», Оперативний штаб Розенберга, ідеологія, пропаганда, більшовизм. 